$\begin{array}{rr}\text { JURNAL } & \text { Volume } 16, \text { Nomor } 1, \text { Januari } 2020 \\ \text { FIT(1)PATOLOGI } & \text { Halaman } 21-29 \\ \text { I N D O N E S I A } & \text { DOI: } 10.14692 / \text { jfi.16.1.21-29 } \\ \text { ISSN: 0215-7950 }\end{array}$

\title{
Laju Fotosintesis Pada Tanaman Kelapa Sawit Terinfeksi Karat Daun Cephaleuros virescens
}

\author{
Photosynthesis Rate of Oil Palm Infected by Red Rust \\ Cephaleuros virescens
}

\author{
Agus Susanto*, Agus Eko Prasetyo, Hari Priwiratama, Muhdan Syarovi \\ Pusat Penelitian Kelapa Sawit, Medan 20158
}

\begin{abstract}
ABSTRAK
Kejadian penyakit karat daun kelapa sawit yang disebabkan alga Cephaleuros virescens semakin meningkat di Indonesia. Kerugian karena penyakit ini pada tanaman kelapa sawit belum pernah diukur secara kuantitatif. Penelitian dilakukan untuk mengukur laju fotosintesis pada tanaman kelapa sawit umur 5 tahun dengan 3 kategori serangan yaitu ringan, sedang, dan berat. Hasil pengamatan di Kebun Kalianta menunjukkan bahwa serangan karat daun dimulai dari pelepah bawah ke pelepah atas. Kejadian penyakit juga banyak terjadi pada permukaan atas helaian daun dibandingkan dengan permukaan bawah daun. Titik kritis serangan karat daun dimulai dari daun ke-17 ke atas yang akan menurunkan laju fotosintesis kelapa sawit. Pada daun ke-9 penurunan laju fotosintesis antara intensitas penyakit ringan ke berat sebesar $42.48 \%$ yaitu dari $15.51 \mu \mathrm{mol}$ ke $8.92 \mu \mathrm{mol}$.
\end{abstract}

Kata kunci: Alga, Cephaleuros virescens, fotosintesis, stomata

\begin{abstract}
The incidence of oil palm red rust disease caused by Cephaleuros virescens tends to increase in Indonesia. However, the loses due to this disease has never been measured quantitatively. This study was conducted to measure the rate of photosynthesis on 5-year-old palms with 3 infection categories, i.e. mild, medium, and heavy infection. Field observation of oil palm in Kalianta showed that the infection of red rust disease occurred starting from lower to the upper fronds. Higher infection was prevalently on the adaxial than abaxial leaf. The red rust infection on frond number 17 or younger severely affects the photoshynthesis rate of the oil palm. On the palm with heavy infection category, the photosynthesis rate on frond number 9 was decreased up to $42.48 \%$, i.e. from $15.51 \mu \mathrm{mol}$ to $8.92 \mu \mathrm{mol}$, compared to that with mild infection.
\end{abstract}

Key words: Algae, Cephaleuros virescens, photosynthesis, stomata

*Alamat penulis korespondensi: Pusat Penelitian Kelapa Sawit. Jalan Brigjend Katamso No. 51. Medan 20158 Tel: 061-7462477; Faks: 061-7462488. Surel: agusmarihat@gmail.com 


\section{PENDAHULUAN}

Penyakit karat daun kelapa sawit yang disebabkan oleh alga Cephaleuros virescens sudah lama dilaporkan keberadaannya di perkebunan kelapa sawit di Indonesia (Susanto dan Sudhart 2002). Alga C. virescens memiliki lebih dari 600 jenis tanaman inang, termasuk komoditas perkebunan bernilai ekonomi tinggi (Han et al. 2011; Malagi et al. 2011; Pitaloka et al. 2015; Ponmurugan et al. 2010; Ponmurugan et al. 2009; Sunpapao et al. 2017; Sunpapao et al. 2016; van Eesvelde et al. 1993; Vasconcelos et al. 2018; Vasconcelos et al. 2016). Perkembangan alga $C$. virescens terutama dipengaruhi oleh kelembapan udara relatif. Pada kelembapan udara yang rendah, kepadatan populasi alga juga semakin rendah (van Eesvelde et al. 1993).

Awalnya karat daun diduga hanya menyerang tanaman yang lemah akibat cekaman faktor lingkungan yang tidak sesuai atau kekurangan unsur hara (van Eesvelde et al. 1993). Namun alga tersebut juga mampu menyerang tanaman kelapa sawit yang tumbuh subur (George et al. 1996). Pada tanaman kelapa sawit, penyakit karat daun selama ini dianggap tidak merugikan karena lebih banyak menyerang daun-daun tua yang secara periodik akan dipotong ketika panen buah atau pemangkasan pelepah dilakukan. Namun, seiring dengan bertambahnya luasan perkebunan kelapa sawit, insidensi penyakit karat daun dengan intensitas yang berat mulai sering dilaporkan.

Penyakit karat daun memengaruhi proses fotosintesis pada tanaman kelapa sawit, terutama pada intensitas penyakit berat (Turner 1981). Pada komoditas lain penyakit bercak dan karat daun mampu menyebabkan penurunan respon laju fotosintesis (Bassanezi et al. 2001; Macioszek et al. 2019; Roloff et al. 2004), bahkan hingga 60\% (Hanif et al. 2012). Gangguan terhadap proses fotosintesis mengakibatkan kurangnya asupan asimilat yang digunakan selama proses pembentukan dan perkembangan bunga kelapa sawit sehingga dapat memengaruhi produksi tandan buah (Harahap 2000). Akan tetapi, besarnya pengaruh penutupan karat daun terhadap aktivitas fotosintesis kelapa sawit belum banyak dilaporkan. Oleh karena itu, penelitian ini dilakukan untuk menentukan dampak penyakit karat daun terhadap laju fotosintesis tanaman kelapa sawit.

\section{BAHAN DAN METODE}

Penelitian dilakukan pada tanaman kelapa sawit berumur 5 tahun yang terletak di Kebun Kalianta, Kabupaten Rokan Hulu, Riau. Laju fotosintesis dan kerapatan stomata diamati pada tanaman kelapa sawit dengan intensitas penyakit ringan (penutupan karat $<5 \%$ ), sedang (6-25\%), dan berat $(>25 \%)$ ). Pada masing-masing kelompok, laju fotosintesis dan jumlah stomata diamati pada pelepah daun ke9, 17, 25, 33, dan 41 (Gambar 1). Pengukuran laju fotosintesis dilakukan secara in-situ dengan mengukur laju pertukaran gas $\mathrm{CO}_{2}$ dan $\mathrm{H}_{2} \mathrm{O}$ pada setiap sampel daun menggunakan LI6800 portable photosynthesis system (LI-COR). Respon tersebut diukur dengan membuat model simulasi laju fotosintesis terhadap berbagai photosynthetically active radiation (PAR). Nilai PAR yang digunakan ialah $1.400 \mu \mathrm{mol} \mathrm{CO}_{2} \mathrm{~m}^{-2} \mathrm{~s}^{-2}$ dimana setiap kelipatan PAR $\mu \mathrm{mol} \mathrm{CO} \mathrm{m}^{-2} \mathrm{~s}^{-2}$, alat secara

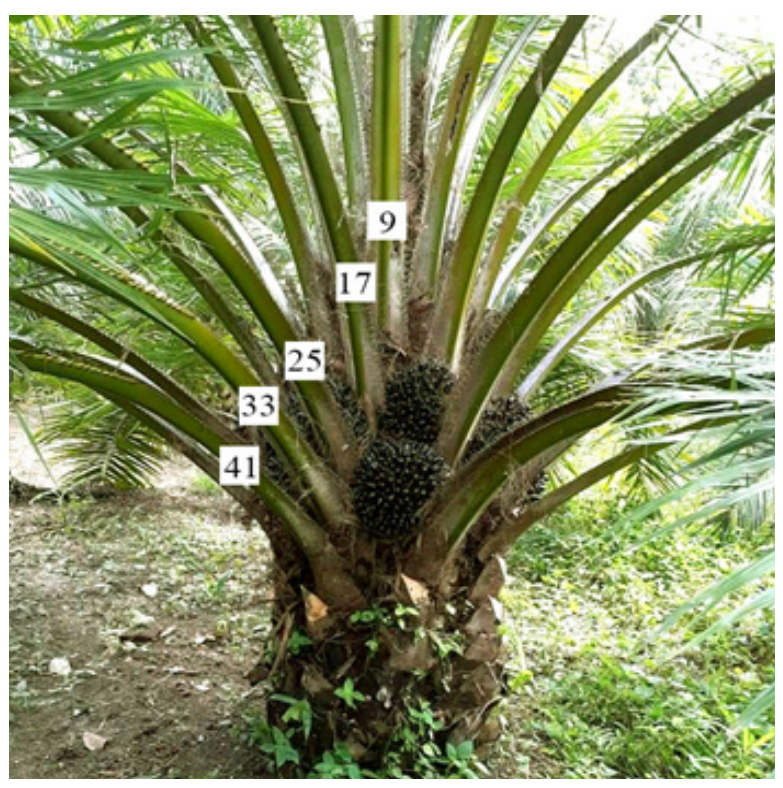

Gambar 1 Kedudukan pelepah kelapa sawit yang digunakan untuk pengukuran laju fotosintesis. 
automatis mencatat nilai laju fotosintes. Untuk mendapatkan satu set simulasi antara laju fotosintesis dan PAR, diperlukan waktu 30-40 menit. Simulasi ini diulang sebanyak 6 kali pada rentang waktu pukul 08.00-12.00 sehingga data-data yang diperoleh merupakan cerminan laju fotosintesis kelapa sawit pada setiap kondisi PAR yang berbeda.

Kerapatan stomata masing-masing sampel daun dihitung berdasarkan metode Pangaribuan et al. (2000), yaitu dengan mengoleskan larutan kuteks pada permukaan bawah daun. Kuteks yang telah mengering dilepas dengan bantuan selotip kemudian direkatkan ke gelas preparat yang telah ditetesi larutan iodine sebagai pewarna. Jumlah stomata dihitung menggunakan mikroskop pada perbesaran $400 \mathrm{x}$.

Data yang diperoleh dianalisis sidik ragam menggunakan perangkat lunak GenStat v.11. Jika terdapat signifikansi data dilanjutkan dengan uji jarak berganda Duncan (Duncan's Multiple Range Test) pada taraf nyata $\alpha 0.05$.

\section{HASIL}

\section{Intensitas Penyakit Karat Daun pada Pelepah Kelapa Sawit}

Intensitas penyakit karat daun semakin berat pada pelepah dengan posisi yang lebih rendah. Sebagai contoh pada tanaman dengan kategori keparahan penyakit berat, intensitas karat pada daun di pelepah ke-17, 25, 33, dan 41 berturut-turut ialah sebesar $6.37 \%$, $37.14 \%$, 50.98\%, dan 54.59\% (Gambar 2). Pola yang sama juga terlihat pada kategori tanaman tingkat keparahan penyakit ringan maupun sedang. Hasil pengamatan ini menunjukkan bahwa alga $C$. virescens cenderung menginfeksi daun pada pelepah yang lebih tua.

\section{Laju Fotosintesis pada Berbagai Tingkat Keparahan Penyakit}

Secara umum, laju fotosintesis pada daun dengan intensitas penyakit karat daun berat lebih rendah dibandingkan dengan intensitas penyakit karat daun sedang dan ringan, baik pada sampel daun termuda (pelepah ke-9) maupun daun tertua (pelepah ke-41)(Gambar3). Pada pelepah ke-9, laju fotosintesis pada intensitas penyakit ringan sebesar $15 \mu \mathrm{mol}$ $\mathrm{CO}_{2} \mathrm{~m}^{-2} \mathrm{~s}^{-1}$, lebih tinggi dibandingkan dengan intensitas penyakit sedang dan berat dengan laju fotosintesis berturut-turut sebesar 14.09 dan $8.92 \mu \mathrm{mol} \mathrm{CO} \mathrm{m}^{-2} \mathrm{~s}^{-1}$. Pola laju fotosintesis yang sama juga terlihat pada seluruh pelepah daun yang diamati.

Selain dipengaruhi oleh intensitas penyakit karat daun, laju fotosintesis pada daun juga dipengaruhi oleh posisi atau umur

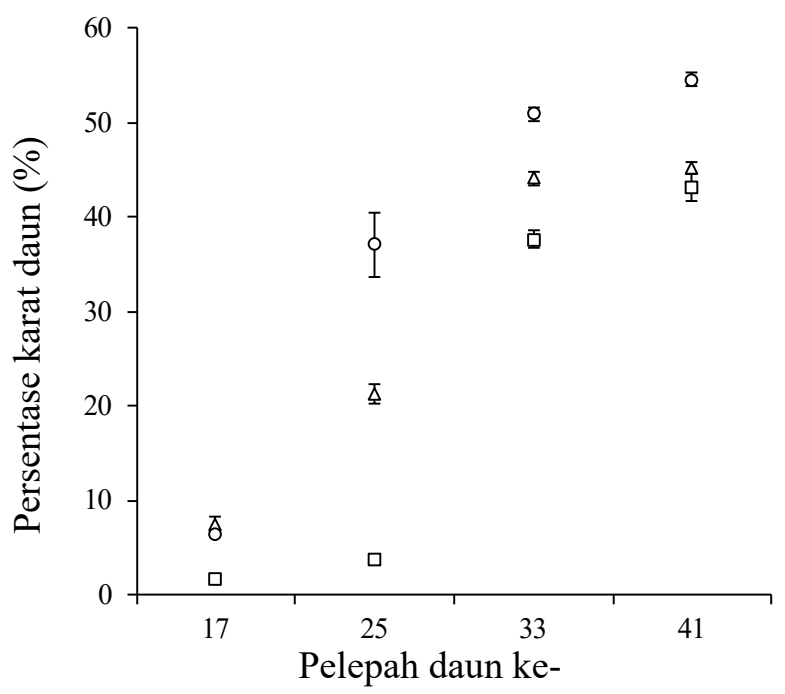

Gambar 2 Persentase karat yang menutupi permukaan daun pada tiap kategori intensitas penyakit. $\square$, Ringan; $\Delta$, Sedang; $\circ$, Berat.

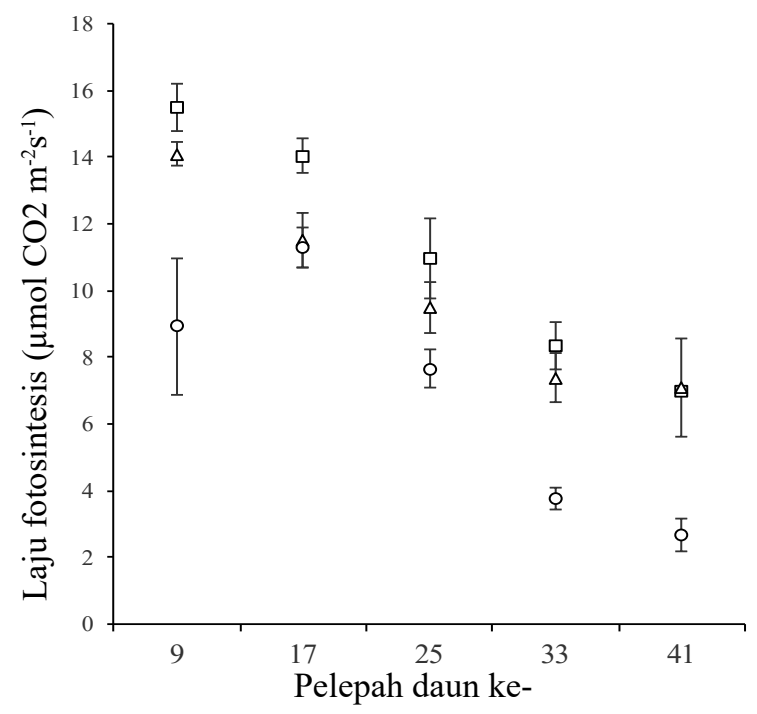

Gambar 3 Laju fotosintesis di setiap pelepah daun pada tiap kategori intensitas penyakit. $\square$, Ringan; $\Delta$, Sedang; $\odot$, Berat. 
pelepah daun. Secara umum, laju fotosintesis cenderung menurun dengan bertambahnya umur pelepah. Semakin tua umur pelepah maka laju fotosintesis menjadi semakin lambat. Sebagai contoh pada tanaman dengan intensitas serangan ringan, nilai laju fotosintesis daun pada pelepah ke-9, 17, 25, 33, dan 41 berturut-turut sebesar 15.51; $14.04 ; 10.98 ; 8.35$; dan $7.08 \mu \mathrm{mol} \mathrm{CO} \mathrm{CO}^{-2} \mathrm{~s}^{-1}$ (Gambar 3). Perbedaan laju fotosintesis antara tanaman sehat dan tanaman sakit tidak dapat dibandingkan dengan penelitian ini karena seluruh tanaman yang ada di areal percobaan telah terinfeksi karat daun. Oleh karena itu, laju penurunan fotosintesis hanya dibandingkan antara tanaman bergejala ringan dengan tanaman bergejala berat. Penurunan laju fotosintesis tertinggi pada tanaman dengan intensitas penyakit ringan ke berat terjadi pada pelepah ke-41 sebesar $61.85 \%$ dan terendah pada pelepah ke-17 sebesar $19.56 \%$. Sementara itu pada pelepah daun termuda (daun ke-9), penurunan laju fotosintesis dari intensitas penyakit ringan ke berat sebesar $42.48 \%$ dari $15.51 \mathrm{ke} 8.92 \mu \mathrm{mol} \mathrm{CO} \mathrm{m}^{-2} \mathrm{~s}^{-1}$.

Secara umum, laju fotosintesis berkorelasi negatif terhadap intensitas penyakit karat daun pada pelepah kelapa sawit dengan koefisien korelasi (R) sebesar 0.74 (Gambar 4). Semakin tinggi penutupan alga pada permukaan daun kelapa sawit maka laju fotosintesisnya semakin berkurang. Laju penurunan fotosintesis terjadi lebih cepat pada pelepah muda, terutama pelepah daun ke17. Melalui persamaan linear yang diperoleh pada daun ke-17 dapat diketahui bahwa potensi penurunan laju fotosintesis mencapai $34 \%$ untuk tingkat intensitas penyakit $10 \%$ (Gambar 5). Sedangkan pada daun yang lebih tua (pelepah ke-33 dan ke-41) penurunannya mencapai $15 \%$ untuk tingkat intensitas penyakit yang sama.

\section{Jumlah Stomata Aktif pada Berbagai Tingkat Intensitas Penyakit Karat Daun}

Pengaruh karat daun juga tampak pada parameter jumlah stomata yang aktif, khususnya pada permukaan atas daun. Karat daun memang sebagian besar menempel pada permukaan atas helaian daun dan berbanding lurus dengan tingkat intensitas penyakitnya. Jumlah stomata pada daun dengan tingkat intensitas penyakit ringan, sedang, dan berat berturut-turut sebanyak 49, 35, dan 24.67 (Tabel 1). Sementara itu jumlah stomata pada daun yang tidak terinfeksi karat daun mencapai 56.67. Jumlah ini lebih tinggi dibandingkan daun dengan tingkat intensitas penyakit sedang dan berat. Sebaliknya pada permukaan bawah daun tidak terdapat perbedaan nyata pada

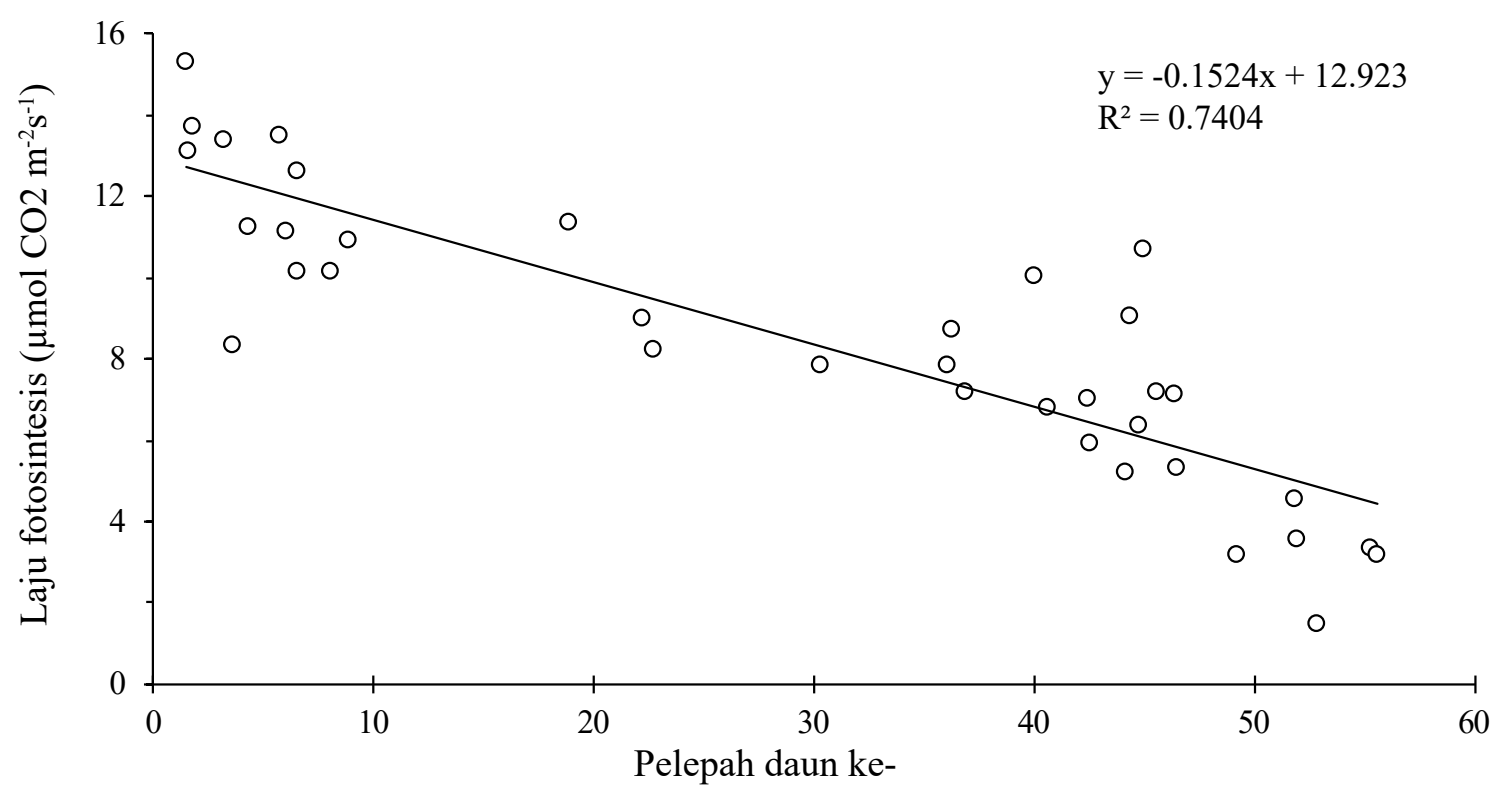

Gambar 4 Hubungan antara intensitas penyakit karat daun dan laju fotosintesis daun kelapa sawit. 


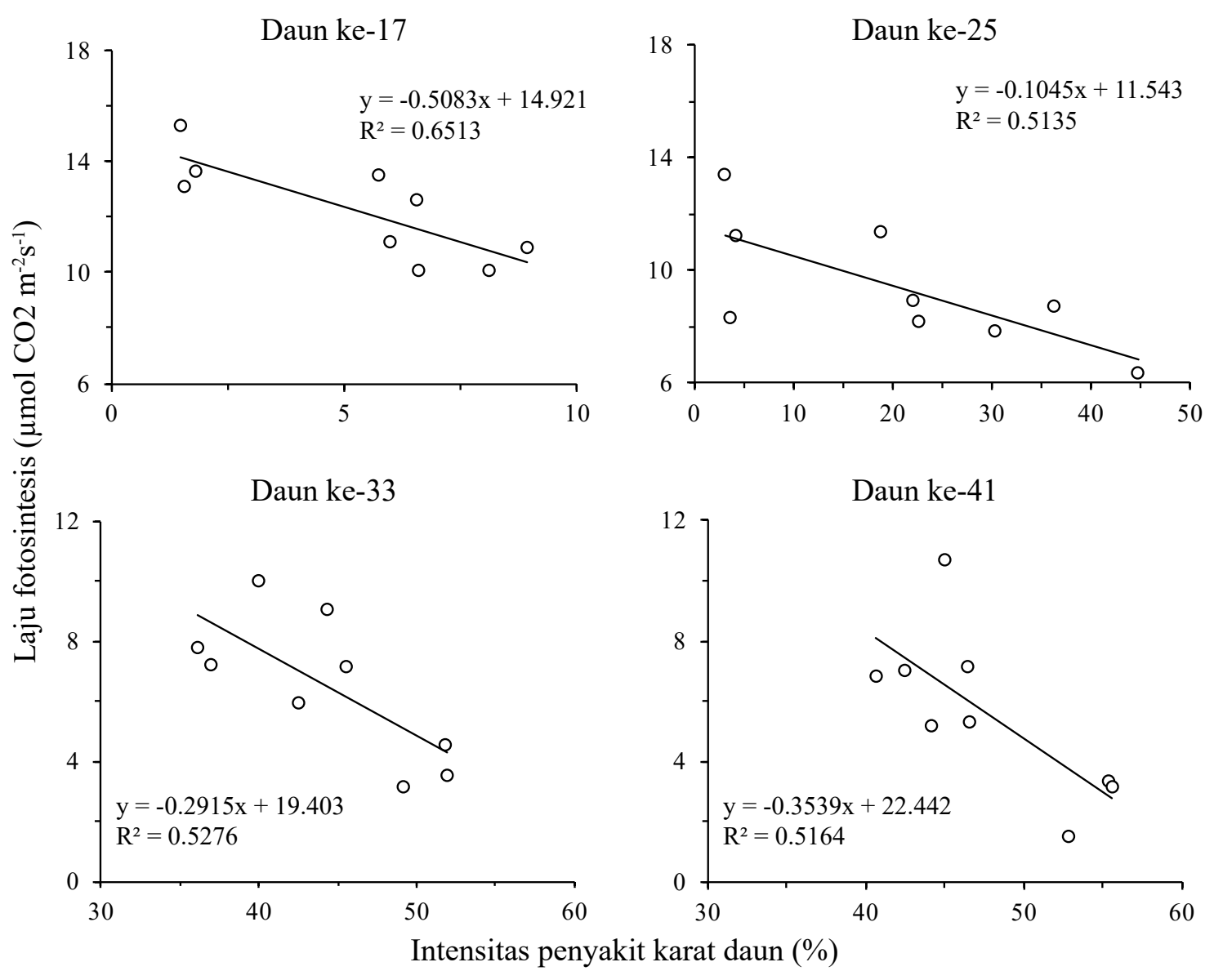

Gambar 5 Hubungan antara intensitas penyakit karat daun dan laju fotosintesis pada daun kelapa sawit ke-17, 25, 33, dan 41.

Tabel 1 Jumlah stomata daun kelapa sawit pada berbagai intensitas penyakit karat daun

\begin{tabular}{lcc}
\hline \multirow{2}{*}{ Kategori intensitas penyakit } & \multicolumn{2}{c}{ Jumlah stomata pada tiap permukaan daun $\left(\right.$ per $\left.\mathrm{cm}^{2}\right)$} \\
\cline { 2 - 3 } & Atas & Bawah \\
\hline Ringan & $49.00 \mathrm{ab}$ & $96.67 \mathrm{a}$ \\
Sedang & $35.00 \mathrm{bc}$ & $95.33 \mathrm{a}$ \\
Berat & $24.67 \mathrm{~b}$ & $106.00 \mathrm{a}$ \\
Sehat (Kontrol) & $56.67 \mathrm{a}$ & $114.67 \mathrm{a}$ \\
\hline
\end{tabular}

jumlah stomata antara daun yang terinfeksi dan daun sehat.

\section{PEMBAHASAN}

Alga $C$. virescens yang ditemukan pada tanaman kelapa sawit bersifat epifit atau hanya menumpang hidup pada daun kelapa sawit (Susanto dan Sudhart 2002). Pada umumya, $C$. virescens dijumpai menempel pada permukaan atas daun-daun yang berada di pelepah bagian bawah atau pelepah tua. Hal ini dapat disebabkan kondisi mikroklimat pada pelepah bagian bawah. Pelepah-pelepah tersebut umumnya terlindungi dari paparan sinar matahari secara langsung, baik karena ternaungi oleh pelepah yang lebih muda atau karena terlindungi dengan pelepah tanaman di sebelahnya. Kondisi ini sangat mendukung untuk perkembangan alga, terutama kadar kelembapan yang lebih tinggi pada pelepah bawah dibandingkan dengan pada daun di pelepah atas atau pelepah muda (Harahap 2000; van Eesvelde et al. 1993).

Pada tanaman kelapa sawit, laju fotosintesis terjadi lebih cepat pada daun-daun muda, terutama pelepah ke-9 hingga pelepah ke-17, dan aktivitasnya semakin menurun 
dengan bertambahnya umur pelepah (Corley dan Tinker 2016; Suresh dan Nagamani 2006). Pelepah-pelepah pada bagian atas memiliki jaringan muda yang lebih peka terhadap cahaya dan memiliki peluang yang lebih besar terpapar radiasi sinar matahari sehingga laju fotosintesisnya menjadi lebih cepat (Harahap 2000). Kecenderungan ini juga terjadi pada berbagai spesies tanaman lainnya (Cano et al. 2013; Lombardini et al. 2009; Martins et al. 2014). Sebaliknya pada pelepah-pelepah tua atau yang berada di bagian bawah, intensitas sinar matahari yang diterima oleh daun berkurang karena ternaungi pelepah diatasnya sehingga respon fotosintesisnya menjadi lebih lambat (Dufrene dan Saugier 1993; Hong dan Corley 1976; Suresh dan Nagamani 2006). Namun Henson (1991b) menyatakan bahwa meskipun respon fotosintesis pada pelepah tua lebih lambat, keberadaan pelepah tua tetap memberikan kontribusi positif terhadap produksi biomassa tanaman kelapa sawit.

Penutupan karat daun yang disebabkan oleh $C$. virescens menyebabkan berkurangnya luas permukaan daun yang aktif berfotosintesis (Nelson 2008; Sunpapao et al. 2016; Turner 1981). Penutupan karat daun pada pelepahpelepah bawah tidak banyak memberikan pengaruh terhadap efektivitas fotosintesis tanaman karena secara alami laju fotosintesis pada daun-daun tersebut sudah lambat (Harahap 2000). Namun pada intensitas penyakit berat, infeksi karat dapat terjadi hingga ke daun muda seperti daun ke-17 sehingga mampu menyebabkan penurunan laju fotosintesis yang signifikan. Dalam jangka panjang, hambatan pada proses fotosintesis dapat berdampak terhadap penurunan biomasa dan produktivitas tanaman. Terhambatnya proses fotosintesis berpotensi menyebabkan penurunan produksi asimilat yang diperlukan untuk pertumbuhan tanaman serta pembentukan dan perkembangan bunga (Harahap 2008; Legros et al. 2009a; Pallas etal. 2013). Asimilat yang terbentuk akan digunakan terlebih dahulu untuk perkembangan vegetatif tanaman dan kelebihannya dimanfaatkan untuk pembentukan dan perkembangan bunga hingga menjadi tandan buah segar yang dapat dipanen (Henson 1990; Corley dan Tinker 2016). Kekurangan hasil asimilat akan menyebabkan tanaman memproduksi lebih banyak bunga jantan bahkan menyebabkan terjadinya aborsi pada bunga yang sudah terbentuk (Pallas et al. 2013).

Daun kelapa sawit memiliki stomata yang aktif pada kedua sisi permukaannya dengan jumlah di bagian bawah 3-5 kali lebih banyak dibandingkan dengan bagian atas (Corley dan Tinker 2016; Henson 1991a). Jumlah stomata yang aktif dapat diindikasikan dari respon laju fotosintesis tanaman yang lebih baik. Umumnya semakin banyak jumlah stomata yang aktif maka laju fotosintesis semakin tinggi (Syarovy et al. 2018). Penutupan permukaan daun yang disebabkan alga $C$. virescens menyebabkan mekanisime membuka dan menutupnya (konduktivitas) stomata terganggu tidak hanya pada permukaan atas, tetapi diduga juga mempengaruhi stomata di bagian bawah. Hal ini dicerminkan dari respon laju fotosintesis lebih rendah pada tanaman dengan serangan karat daun berat.

Stomata berperan sebagai tempat masuknya gas $\mathrm{CO}_{2}$ dan mengeluarkan kelebihan gas $\mathrm{O}_{2}$ yang bersifat toksik bagi selsel daun. Keberadaan karat daun pada bagian atas permukaan daun menyebabkan jumlah stomata yang aktif menjadi lebih rendah dibandingkan dengan daun yang sehat. Pada area yang terpapar karat daun, stomata akan tetap menutup sehingga mengurangi jalan masuknya gas $\mathrm{CO}_{2}$. Selain disebabkan infeksi karat daun, penutupan stomata juga dapat dipicu oleh faktor-faktor lainnya seperti suhu udara atau kekeringan (Legros et al. 2009b; Ruiz dan Henson 2002; Suresh dan Nagamani 2006; Suresh et al. 2010).

Epidemi penyakit karat daun sangat dipengaruhi oleh curah hujan dan kelembapan yang tinggi, kondisi hara tanah dan tanaman, drainase yang kurang baik atau daerah tergenang (Nelson 2008). Di perkebunan kelapa sawit penyakit karat daun lebih banyak ditemukan di daerah lembap di dekat sungai atau daerah dengan pertumbuhan gulma yang tidak terkendali. Penyakit karat daun juga banyak terjadi pada tanaman kelapa sawit 
yang terletak di tepi jalan, terutama jalan tanah yang banyak menghasilkan debu. Dari hasil pengamatan, daun-daun yang tertutupi debu menjadi lebih rentan terhadap C. virescens. Peran debu terhadap pertumbuhan alga $C$. virescens diduga menyediakan nutrisi yang diperlukan untuk pertumbuhan alga (Susanto dan Sudharto 2002).

Penyakit karat daun harus dikendalikan apabila infeksinya telah mencapai daun-daun muda. Pengendalian penyakit karat daun dilakukan dengan pemangkasan pelepah dengan tetap mempertahankan jumlah pelepah optimal, yaitu sebanyak 48-56 untuk tanaman kelapa sawit berumur kurang dari 8 tahun dan 40-48 pelepah untuk tanaman yang berumur diatasnya. Pemangkasan pelepah ini juga akan menurunkan tingkat kelembapan dan menurunkan jumlah inokulum. Jika serangan sudah mencapai daun ke-17, perlu dipertimbangkan aplikasi fungisida yang berbahan aktif tembaga atau klorotalonil (Browne et al. 2016; Susanto et al. 2015; Susanto dan Sudhart 2002).

Penutupan karat daun kelapa sawit yang disebabkan oleh alga $C$. virescens lebih banyak terjadi pada permukaan atas daun di pelepah-pelepah bagian bawah atau pelepah tua. Intensitas penyakit karat daun memiliki dampak negatif terhadap respon atau laju fotosintesis kelapa sawit. Semakin tinggi intensitas penyakit, laju fotosintesis menjadi semakin rendah dengan penurunan mencapai lebih dari $40 \%$.

\section{DAFTAR PUSTAKA}

Bassanezi RB, Amorim L, Filho AB, Hau B, Berger RD. 2001. Accounting for photosynthetic efficiency of bean leaves with rust, angular leaf spot and anthracnose to assess crop damage. Plant Pathology. 50(4):443-452. DOI: https://doi. org/10.1046/j.1365-3059.2001.00584.x.

Browne FB, Fall LA, Brannen PM, Taylor J, Shealey J, Beasley ED. 2016. Assessment of algicides, disinfectants and fungicides for control of orange cane blotch caused by the alga Cephaleuros virescens. Proceedings of the Acta Horticulturae, 2016: International Society for Horticultural Science (ISHS), Leuven, Belgium. 497-502. DOI: https://doi. org/10.17660/ActaHortic.2016.1133.77.

Cano FJ, Sánchez-Gómez D, RodríguezCalcerrada J, Warren CR, Gil L, Aranda I. 2013. Effects of drought on mesophyll conductance and photosynthetic limitations at different tree canopy layers. Plant, Cell \& Environment. 36(11):1961-1980. DOI: https://doi.org/10.1111/pce.12103.

Corley RHV, Tinker PB. 2016. The Oil Palm. Chichester (UK): Blackwell Science Ltd. DOI: https://doi. org/10.1002/9781118953297.

Dufrene E, Saugier B. 1993. Gas exchange of oil palm in relation to light, vapour pressure deficit, temperature and leaf age. Functional Ecology. 7(1):97-104. DOI: https://doi.org/10.2307/2389872.

George ST, Chung GF, Balasubramaniam R. 1996. Fungicide screening for the control of algal leaf spots on oil palm. Proceedings of the PIPOC International Palm Oil Congress 1996. Kuala Lumpur: MPOB. 516-520.

Han K-S, Park M-J, Park J-H, Shin H-D. 2011. First report of algal leaf spot associated with Cephaleuros virescens on greenhouse-grown Ficus benghalensis in Korea. Aust Plant Dis Notes. 6(1):72-73. DOI: https://doi.org/10.1007/s13314-0110024-8.

Hanif A, Suryanto D, Nurwahyuni I. 2012. Pemanfaatan bakteri kitinolitik dalam menghambat pertumbuhan Curvularia sp. penyebab penyakit bercak daun pada tanaman mentimun. J Saintia Biologi. 1(1):26-32.

Harahap IY. 2000. Pola respon laju fotosintesis kelapa sawit terhadap perubahan mikroklimat. Warta PPKS. 8(2):79-87.

Harahap IY. 2008. Kajian diferensiasi jenis kelamin pada pembentukan bunga kelapa sawit (Elaeis guineensis Jacq.) melalui pendekatan kuantitatif-statistik. Jurnal Penelitian Kelapa Sawit. 16(1):47-54. 
Henson IE. 1990. Photosynthesis and sourcesink relationships in oil palm (Elaeis guineensis). Transactions Malaysian Society of Plant Physiology. 1:165-171.

Henson IE. 1991a. Age-related changes in stomatal and photosynthetic characteristics of leaves of oil palm. Elaeis. 3:336-348.

Henson IE. 1991b. Limitations to gas exchange, growth and yield of young oil palm by soil water supply and atmospheric humidity. Transactions Malaysian Society of Plant Physiology. 2:39-45.

Hong T, Corley R. 1976. Leaf temperature and photosynthesis of a tropical C3 plant, Elaeis guineensis. MARDI Research Bulletin. 4(1):16-20.

Legros S, Mialet-Serra I, Caliman J-P, Siregar FA, Clément-Vidal A, Fabre D, Dingkuhn M. 2009a. Phenology, growth and physiological adjustments of oil palm (Elaeis guineensis) to sink limitation induced by fruit pruning. Annals of Botany. 104(6):1183-1194. DOI: https:// doi.org/10.1093/aob/mcp216.

Legros S, Mialet-Serra I, Clement-Vidal A, Caliman J-P, Siregar FA, Fabre D, Dingkuhn M. 2009b. Role of transitory carbon reserves during adjustment to climate variability and source-sink imbalances in oil palm (Elaeis guineensis). Tree Physiology. 29(10):1199-1211. DOI: https://doi.org/10.1093/treephys/tpp057.

Lombardini L, Restrepo-Diaz H, Volder A. 2009. Photosynthetic light response and epidermal characteristics of sun and shade pecan leaves. J Am Soc Horticul Sci. 134(3): 372-378. DOI: https://doi. org/10.21273/JASHS.134.3.372.

Macioszek VK, Wielanek M, Morkunas I, Ciereszko I, Kononowicz AK. 2019. Leaf position-dependent effect of Alternaria brassicicola development on host cell death, photosynthesis and secondary metabolites in Brassica juncea. Physiologia Plantarum. 2019:1-16. DOI: https://doi.org/10.1111/ppl.12998.

Malagi G, Santos ID, Mazaro S, Guginski C. 2011. Detection of algal leaf spot (Cephaleuros virescens Kunze) in citrus in Paraná state. Revista Brasileira de Agrociência. 17(1):148-152.

Martins SCV, Galmés J, Cavatte PC, Pereira LF, Ventrella MC, Damatta FM. 2014. Understanding the low photosynthetic rates of sun and shade coffee leaves: bridging the gap on the relative roles of hydraulic, diffusive and biochemical constraints to photosynthesis. Plos One. 9(4):e95571. DOI: https://doi.org/10.1371/journal. pone.0095571.

Nelson SC. 2008. Cephaleuros species, the plant-parasitic green algae. University of Hawai'i at Manoa, College of Tropical Agriculture and Human.

Pallas B, Mialet-Serra I, Rouan L, ClémentVidal A, Caliman J-P, Dingkuhn M. 2013. Effect of source/sink ratios on yield components, growth dynamics and structural characteristics of oil palm (Elaeis guineensis) bunches. Tree Physiology. 33(4):409-424. DOI: https:// doi.org/10.1093/treephys/tpt015.

Pangaribuan Y, Sudrajat, Asmono D. 2000. Respon fisiologi beberapa varietas kelapa sawit di pembibitan terhadap cekaman air. Jurnal Penelitian Kelapa Sawit. 8(2):8195.

Pitaloka MK, Petcharat V, Arikit S, Sunpapao A. 2015. Cephaleuros virescens, the cause of an algal leaf spot on Para rubber in Thailand. Aust Plant Dis Notes. 10(1):4. DOI: https://doi.org/10.1007/s13314-0150158-1.

Ponmurugan P, Saravanan D, Ramya M. 2010. Culture and biochemical analysis of a tea algal pathogen, Cephaleuros parasiticus. J Phycology. 46(5):10171023. DOI: https://doi.org/10.1111/j.15298817.2010.00879.x.

Ponmurugan P, Saravanan D, Ramya M, Srinivasan T, Baby U, Ajay D. 2009. Studies on Cephaleuros parasiticus Karst, a pathogenic alga causing red rust disease in tea plantations. J Plantation Crops. 37(1):70-73.

Roloff I, Scherm H, Van Iersel MW. 2004. Photosynthesis of blueberry leaves as affected by septoria leaf spot and abiotic 
leaf damage. Plant Disease. 88(4):397401. DOI: https://doi.org/10.1094/ PDIS.2004.88.4.397.

Ruiz R, Henson I. 2002. Photosynthesis and stomatal conductance of oil palm in Colombia: some initial observations. Planter. 78(915):301-308.

Sunpapao A, Bunjongsiri P, Thithuan N, Arikit S. 2017. First report of Cephaleuros virescens causing algal leaf spot of Manilkara zapota in Thailand. Plant Dis. 101(4):636. DOI: https://doi.org/10.1094/ PDIS-08-16-1111-PDN.

Sunpapao A, Pitaloka MK, Arikit S. 2016. Algal leaf spot associated with Cephaleuros virescens 1 Ulvophyceae. Biodiversitas. 17(1):31-35. DOI: https:// doi.org/10.13057/biodiv/d170105.

Suresh K, Nagamani C. 2006. Variations in photosynthetic rate and associated parameters with age of oil palm leaves under irrigation. Photosynthetica. 44(2):309311. DOI: https://doi.org/10.1007/s11099006-0023-8.

Suresh K, Nagamani C, Ramachandrudu K, Mathur RK. 2010. Gas-exchange characteristics, leaf water potential and chlorophyll a fluorescence in oil palm (Elaeis guineensis Jacq.) seedlings under water stress and recovery. Photosynthetica. 48(3):430-436. DOI: https://doi. org/10.1007/s11099-010-0056-x.

Susanto A, Prasetyo AE, Priwiratama H, Rozziansha TaP, Simanjuntak D, Sipayung
A, Purba RY, Sudharto, De Chenon RD. 2015. Kunci Sukses Pengendalian Hama dan Penyakit Kelapa Sawit. Medan: Pusat Penelitian Kelapa Sawit.

Susanto A, Sudharto PS. 2002. Bioekologi dan pengendalian karat daun Cephaleuros virescens di perkebunan kelapa sawit. Warta PPKS.

Syarovy M, Rahutomo S, Listia E, Susanto A, Prasetyo AE. 2018. Karakteristik morfologi dan fisiologi tanaman abnormalitas kimera bibit kelapa sawit. Warta PPKS. 23(2):7276.

Turner PD. 1981. Oil palm diseases and disorders. Oxford (UK): Oxford Univ Press. Van Eesvelde S, Liau SS, Van Damme P. 1993. Epiphytic and parasitic algae (Trentepohliaceae) on oil palm (Elaeis guineensis Jacq.). General description of species (Cephaleuros virescens and Phycopeltis sp.) and experimental work. AGRIS. 58(3a):1033-1050.

Vasconcelos CV, Pereira FT, Duarte EaA, De Oliveira TaS, Peixoto N, Carvalho DDC. 2018. Physiological and molecular characterization of Cephaleuros virescens occurring in mango trees. The Plant Pathology Journal. 34(3):157-162.

Vasconcelos CV, Pereira FT, Galvão CDS, Carvalho DDC. 2016. Occurrence of algal leaf spot (Cephaleuros virescens Kunze) on avocado in Goiás State, Brazil. Summa Phytopathologica. 42:108-108. DOI: https://doi.org/10.1590/0100-5405/2109. 